Waite, R. \& Gorrod, A. R. N. (1959b). F. Sci. Fd Agric. ro, 3 I7.

Waite, R., Johnston, M. J. \& Armstrong, D, G. (1964). F. agric. Sci. (In the Press.)

Wallace, L. R. (1956). Proc. int. Grassl. Congr. viI. Wellington, N. Zealand, p. I34.

\title{
Ruminal volatile fatty acid production in relation to animal production from grass*
}

\section{By J. A. F. Rоoк, National Institute for Research in Dairying, Shinfield, Reading}

The studies of Sir Joseph Barcroft and his colleagues (Phillipson \& McAnally, I942; Barcroft, McAnally \& Phillipson, 1944) at Cambridge in the early I940s established that the volatile fatty acids (VFAs) produced during the fermentation of foodstuffs within the rumen of sheep and cattle are absorbed through the rumen wall and metabolized by the tissues. It has since been shown (see Annison \& Lewis, 1959) that the VFAs arise largely from fermentation of dietary carbohydrates, and of glycerol liberated on hydrolysis of triglycerides, and that only a small part of the soluble carbohydrates escapes degradation. Also, in addition to the major VFAs present in the rumen-acetic, propionic and n-butyric acids-n-valeric acid and branched-chain isomers of butyric and valeric acids (isobutyric, 2-methylbutyric and isovaleric) have been found in low concentrations, more particularly in animals on protein-rich diets (el-Shazly, 1952a,b; Annison, 1954). Formic acid, although undoubtedly an intermediate in the fermentation processes, is rapidly dissimilated in the rumen and is present only in very low concentrations (Johns, I 955 ; Bensadoun, Paladines \& Reid, 1962). Only traces of lactic acid are found in rumen liquor, with the exception of transient high levels shortly after feeding in animals given diets containing large amounts of cooked, starchy foods (Balch \& Rowland, 1957).

\section{The production of volatile fatty acids in the rumen}

There is still uncertainty as to the exact, quantitative contribution of the acids to energy nutrition in ruminant animals. Hogan \& Phillipson ( 1960 ), from measurements of the flow of digesta in adult sheep given a diet of meadow hay (9 parts), linseed meal (4 parts) and oats ( 2 parts), calculated that, of the apparently digested material of the diet, $70 \%$ left the digestive tract between the mouth and the pylorus. The high energy loss in fermentation, as methane as well as direct heat loss, compared with that in other digestive processes would mean that a smaller proportion of the total absorbed nutrients would be accounted for by the materials absorbed from the rumen, which are mainly VFAs. Small quantities of VFAs are produced also in the hind gut.

A more direct approach to the problem is to measure the ruminal production of VFAs. Because of the continuous production and absorption of the acids and the onward passage of digesta this measurement has proved technically difficult, but various approaches have been devised.

* Read at the joint meeting of The Nutrition Society and the British Grassland Society in London on 5 December 1963. Also published in the Fournal of the British Grassland Society, Vol. 19, No. I, March 1964. 
In vitro techniques. Samples of rumen digesta have been incubated in vitro and the rate of VFA production measured (Gray, Pilgrim \& Weller, 195I). To minimize the effects of the artificial conditions of incubation, the incubation period has been kept short (Halse \& Velle, I956), or the observed curve of VFA production has been extrapolated to zero time to give an estimate of production at the time of sampling (Carroll \& Hungate, I954; Stewart, Stewart \& Schultz, 1958; Hungate, Mah \& Simesen, I96r). Sutherland, Ellis, Reid \& Murray (1962) have introduced a specially designed pump for the continuous circulation of rumen contents to overcome the difficulties of intraruminal sampling. If simultaneous estimates of the volume of digesta are made, the rate of production of the acids can be calculated. As an alternative, Balch (1958) determined in vitro the VFAs produced per unit of digested material and measured simultaneously the extent of digestion within the rumen by a lignin-ratio technique.

Intraruminal infusion technique. Individual acids have been infused at a constant, known rate into the rumen and the basal production of the infused acid was calculated from the observed change in the concentration of the acid relative to that of other acids (Bath, Balch \& Rook, 1962).

Isotope dilution methods. Ruminal production of the acids has been estimated from the dilution of labelled acids introduced into the rumen (Sheppard, Forbes \& Johnson, I 959; Gray, Jones \& Pilgrim, I960) or, by allowing for endogenous production of acetate, from the rate of entry of acetate into the body pool as measured by isotope dilution techniques (Davis, Brown, Staubus \& Nelson, 1960; Annison \& Lindsay, 1961; Essig, Norton \& Johnson, 196r; Lee \& Williams, 1962).

Arterio-venous difference technique. Measurement of the concentrations of the various end-products of digestion in portal venous blood and in arterial blood, coupled with measurements of the rate of flow of portal blood, have given estimates of the quantities of VFAs absorbed from the rumen (Barcroft et al. 1944; Annison, Hill \& Lewis, I957; Bensadoun et al. 1962). Because of the metabolic activities of the rumen wall, the materials appearing in the blood are not identical with those absorbed from the rumen.

Isolated and perfused rumen techniques. The rate of absorption of VFAs added to the washed-out, tied-off rumens of anaesthetized sheep (Danielli, Hitchcock, Marshall \& Phillipson, I945; Pfander \& Phillipson, r953) has been measured, and the isolated rumen, perfused by a heart-lung machine, has been used to estimate the rate of entry of VFAs and their metabolites into portal blood (McCarthy, Shaw, McCarthy, Lakshmanan \& Holter, 1958; Brown, Davis, Staubus \& Nelson, 1960).

There is no absolute check on the validity of any of the methods as a measure of VFA production under normal feeding conditions and several are open to serious criticism for reasons of technique or interpretation (Sutherland, 1963). But all techniques have demonstrated that substantial amounts of VFAs are absorbed from the rumen. Blaxter $(1962)$ has given some estimates of the quantity of acetic acid taken up from the gut of the sheep, calculated from information obtained by the different techniques, which range from 50 to $5^{\circ} \mathrm{g} /$ day, and Carroll ( 1963 ) has summarized observations on VFA production in cattle which show a production 
Vol. 23

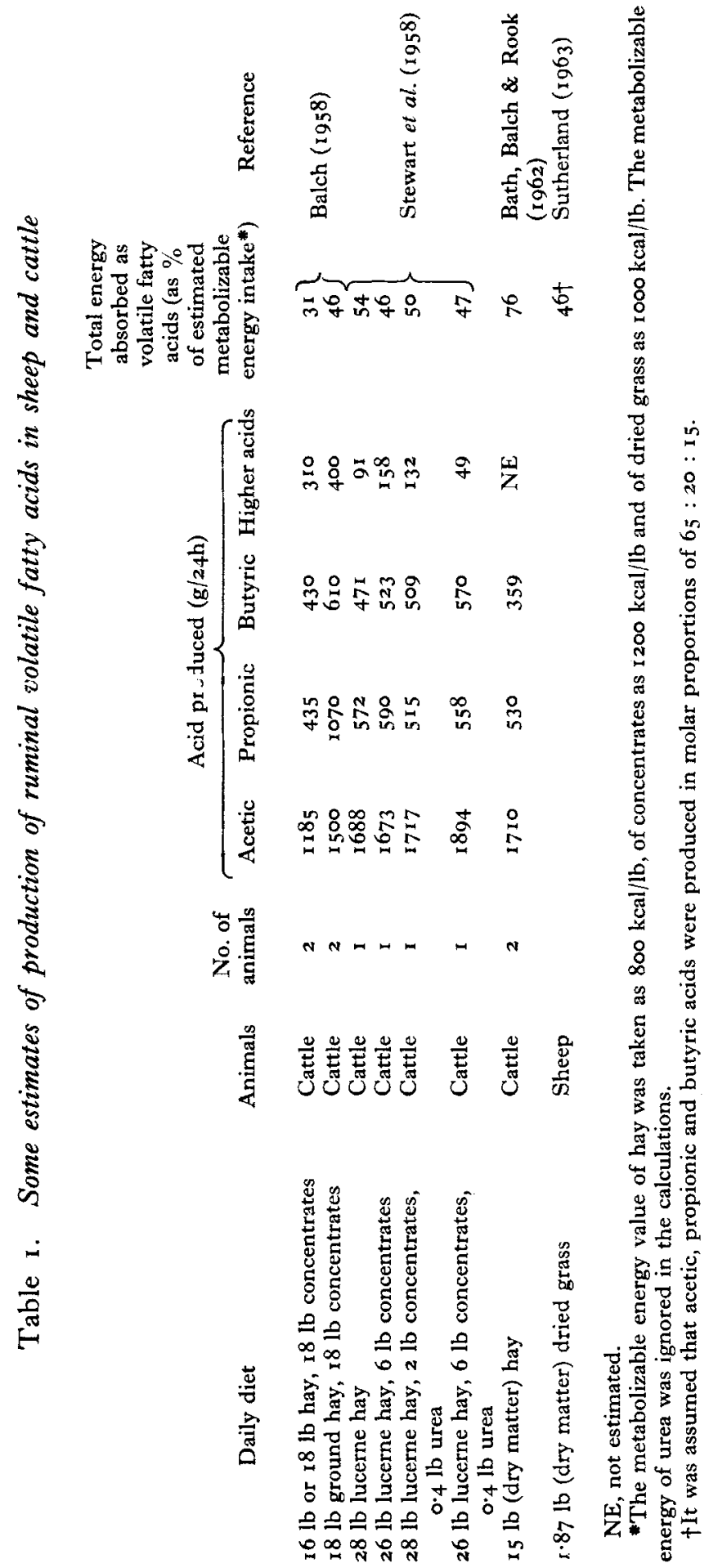


of acetic acid of the order of $1500 \mathrm{~g}(5235 \mathrm{kcal}) /$ day: on a calorie basis, acetic acid usually accounts for less than half of the total acids produced. In only a few instances, however, have the methods been applied in a way that permits the calculation of VFA production per unit of food ingested and those results are given in Table I. The high values obtained by Balch (1958) for the quantity of higher acids produced suggest that fermentation conditions within the rumen were not maintained during the in vitro fermentation of samples of digesta used to estimate production, which may explain the low values for acid production in one trial. The other estimates indicate that the energy value of VFAs absorbed from the rumen accounts for at least half of the intake of metabolizable energy.

\section{$V$ ariations with diet in the ruminal concentrations of volatile fatty acids}

In the absence of a satisfactory routine procedure for the measurement of VFA production, information has been obtained on the concentration of the total and individual VFAs in the rumen digesta of animals given various diets. Concentration is a major factor determining the rates of absorption of VFAs from the rumen but the $\mathrm{pH}$ of the rumen contents also is important, and butyric acid, and to a lesser extent propionic acid, are absorbed from the rumen more readily than acetic acid (Pfander \& Phillipson, I953; Sutherland, I963): the contrary evidence (Gray \& Pilgrim, I 95 I; McCarthy et al. 1958; Brown et al. I960) is inadmissible for technical reasons. There is no possibility, therefore, of using total VFA concentration or the concentration of individual acids as a measure of their production within the rumen. Even in comparative terms, total VFA concentration, though it has been shown to be related to the dry-matter intake (Williams \& Christian, 1956), must be a poor index because of the known variation in the volume of digesta throughout a feeding cycle and from diet to diet: for many purposes it would be more satisfactory to assume that total VFA production is rectilinearly related to the intake of metabolizable energy. The relative concentrations of the individual VFAs should, however, serve to characterize the pattern of fermentation.

It cannot be overemphasized, though, that, for a given diet, the observed ratios for the VFAs may vary with the part within the rumen from which samples of digesta are taken, and certainly with the interval after feeding and the level and frequency of feeding (Bath \& Rook, I963). The variations may not always reflect a change in the relative production of the acids but simply an alteration in the equilibrium between ruminal concentration and rate of absorption. It is essential therefore to standardize feeding conditions and the procedure and routine for the sampling of digesta, if comparisons made between foods are to be meaningful: contrary to the conclusions of Shaw (196I), sampling at regular intervals throughout a feeding cycle would appear to be essential. This is especially true for comparisons made over the fairly narrow range of values found for the majority of diets offered to cattle and sheep under farming conditions. In addition, the observed ratios for VFAs vary from animal to animal, and possibly within an animal from time to time, and these variations are generally more marked with diets that typically give a low proportion of acetic acid and high proportions of propionic and butyric acids. These 
$s$

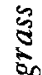

b.

:

先

से

3

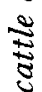

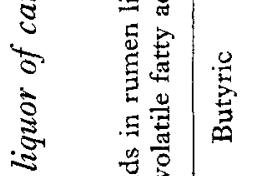

离

$\approx$

.\$

: 30

ช

$\frac{3}{3}$

के

है

in

$\frac{0}{0}$<smiles>CC(C)c1ccccc1</smiles>

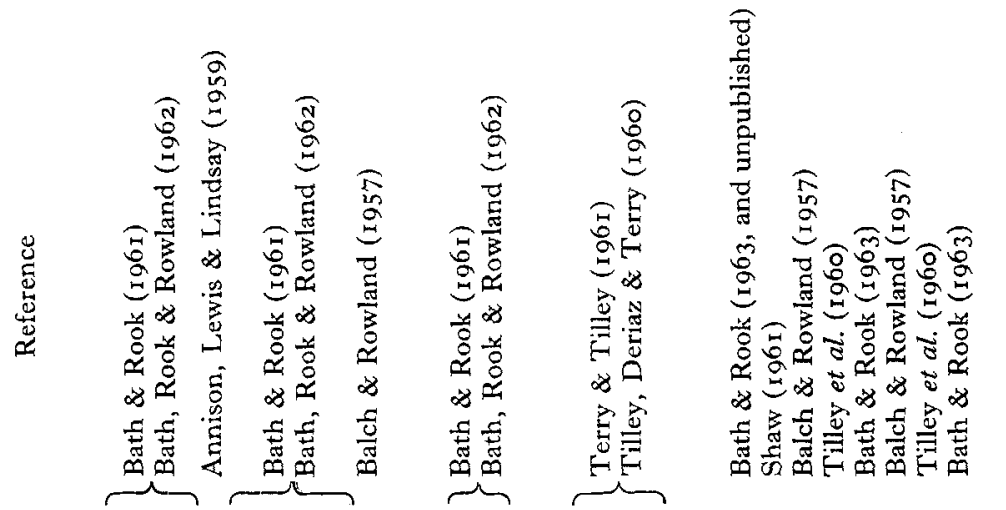

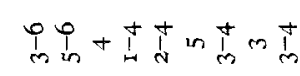

in

을을

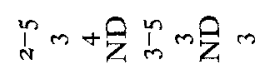

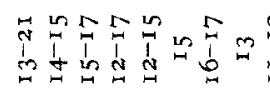

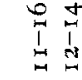

$\begin{array}{lll}0 & 0 \\ 0 & 0 & 1 \\ 0 & 0 & 1\end{array}$

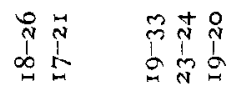

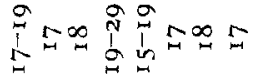

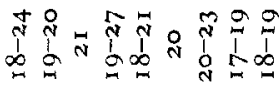

Dog

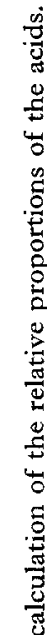

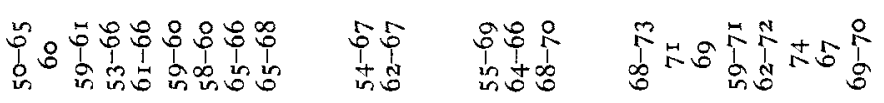

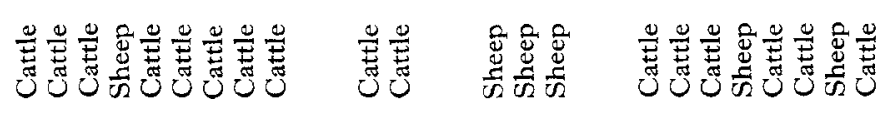

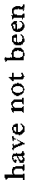

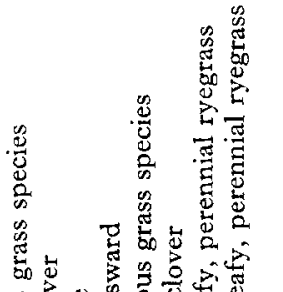

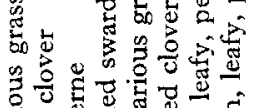

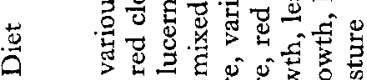

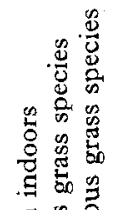

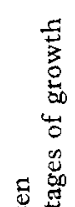

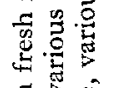

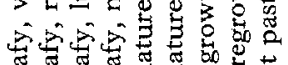

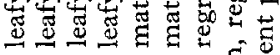

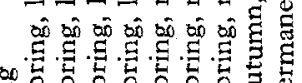

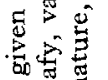

的密焉

要

\begin{tabular}{l}
8 \\
\multirow{4}{*}{5} \\
3
\end{tabular}

造

हี

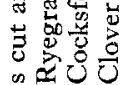

क

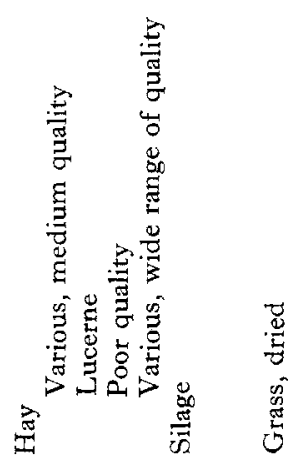


points must be borne in mind in any evaluation of the effect of diet on VFA proportions in rumen liquor.

Some of the results obtained for grass and grass products are summarized in Table 2. There is a wide range in the published values for all classes of foodstuffs. It is particularly so for the values reported for spring grass at a leafy stage of growth which vary from 50 to $67 \%$ for the proportion of acetic acid, from 18 to $33 \%$ for that of propionic acid and from 10 to $21 \%$ for that of butyric acid, when expressed as a molar percentage of the total VFA concentration in rumen liquor. A part of this variation is accounted for by differences between grass species. The higher proportions of propionic acid reported are for ryegrass preserved by deep freezing and offered ad lib. to sheep. A narrower range of values $(59-68 \%$ for acetic acid, $17-21 \%$ for propionic acid, $I-15 \%$ for butyric acid), and on average a higher proportion of acetic acid and lower proportions of propionic and butyric acids, have been obtained for spring grass at a mature stage of growth and for autumn grass. Values obtained for grazing animals tend to show a lower proportion of acetic acid and a higher proportion of butyric acid than those for animals given the same sward cut and offered fresh twice daily in the stall: this could be the result of selective grazing, of a greater herbage intake or of continuous access to the sward.

The majority of hays and silages examined have given high values $\left(6_{5}-75 \%\right)$ for the proportion of acetic acid. Particularly low values for butyric acid $(8-12 \%)$ were found with the hays and some of the silages. Other silages were characterized by a particularly low proportion of propionic acid (as low as $15 \%$ ), but for most of the hays and silages the proportion of propionic acid was within the range of $17-19 \%$. Values of $59 \%$ for the proportion of acetic acid and of $29 \%$ for propionic acid have, however, been reported for a hay of excellent quality offered to sheep (Tilley et al. 1960). Also, the fine grinding of hay has been shown (Wright, Pope \& Phillips, 1963) to decrease markedly the proportion of acetic acid and to increase the proportions of propionic and butyric acids.

The addition of concentrates to diets of hay and silage (Bath \& Rook, 1963, and unpublished observations) has usually, but not invariably, caused a decrease in the proportion of acetic acid. The extent of the depression, and whether compensation occurred primarily in propionic or butyric acid, has varied markedly from cow to cow and with the type of concentrate offered. In general, compensation in propionic acid was associated with a more marked depression in acetic acid than was compensation in butyric acid and occurred most frequently with concentrates containing a high proportion of cooked starchy foods. In practical terms, an increase in the proportion of propionic acid is more likely to occur with a supplement of flaked maize than with one of rolled barley. The values obtained for the proportions of acetic, propionic, butyric and valeric acids in single experiments with cattle, with diets consisting solely of flaked maize or rolled barley are $34: 46: 6: 14$ (Shaw, 1961) and $55: 22:$ I $8: 5$ (Bath \& Rook, unpublished) respectively.

An inverse relationship between the soluble carbohydrate content of the diet and the proportion of acetic acid in the VFAs of rumen liquor has been noted in comparative studies with different ryegrass swards (Terry \& Tilley, 196r; Bath \& 
Rook, I96I), but much of the association has been lost when the comparison has included other grass species (Bath, Rook \& Rowland, 1962). As mentioned previously, there is a tendency for the proportion of the branched-chain higher acids to be greatest with diets rich in protein. Though the chemical composition of the diet is clearly an important factor affecting the proportions of the VFAs in rumen liquor, the microflora, which will be influenced by both the chemical and physical nature of the diet, must be of equal or greater importance. It is apparent that the cellulolytic organisms that develop on high-roughage diets are characterized, in mixed culture, by a high proportion of acetic acid in the end-products of their metabolism and that, with the addition of concentrates, there can be a preferential development of organisms producing a high proportion of propionic acid or of organisms producing a high proportion of butyric acid. Which type of organism develops must be dependent on the supplement, the rumen flora established with the previous diet and perhaps on other, physiological factors peculiar to the individual animal.

\section{The utilization of volatile fatty acids}

On absorption from the rumen, the VFAs are metabolized in distinctly different ways. Propionate and butyrate are metabolized almost wholly in the rumen wall and liver and are present in very low concentrations in peripheral blood, whereas acetate is metabolized to only a small extent in those tissues and a large part of that absorbed from the rumen enters the peripheral circulation (Annison et al. 1957). Also, propionate is glucogenic whereas butyrate is ketogenic and, contrary to much earlier evidence, does not give rise to a net synthesis of glucose within the body (Annison, Leng, Lindsay \& White, 1963). The acids have, therefore, markedly different effects on the supply of metabolites to the peripheral tissues (Armstrong \& Blaxter, 1957a,b; Armstrong, Blaxter \& Graham, 1957; Storry \& Rook, 1961) and changes in the uptake of individual acids from the rumen would be expected to have different quantitative and qualitative effects on productive processes within the body.

Blaxter and his colleagues (Armstrong \& Blaxter, 1957b; Armstrong et al. I957; Armstrong, Blaxter, Graham \& Wainman, I958) have shown that though different mixtures of VFAs are used with about the same efficiency as a source of energy for maintenance, the efficiency with which the absorbed products of digestion are used for lipogenesis is higher when the VFAs of rumen liquor contain a high proportion of propionic and butyric acids than when they contain a high proportion of acetic acid. Differences in the ability of the acids to promote nitrogen retention have not been demonstrated in 2-year-old heifers in good condition (Rook, Balch, Campling \& Fisher, 1963) but a further evaluation needs to be made with younger animals with a greater potential for growth. In the milking cow (Rook $\&$ Balch, r96r), the addition of individual acids to the rumen has produced characteristic responses in the yield and composition of milk. Acetic acid gave an increase in the yield of milk and a specific increase in the fat content. Propionic and butyric acids were without effect on milk yield but propionic acid depressed fat content and increased protein 
and therefore solids-not-fat contents, and butyric acid had the single effect of increasing fat content.

\section{The end-products of fermentation in relation to the utilization of dietary energy}

The effect of the proportion of individual acids in the mixture of VFAs metabolized on the efficiency of fat synthesis raises the possibility that the fine grinding of roughage and the cooking of concentrates in a diet, which increase the ruminal production of propionic acid relative to that of acetic acid, would give an improved live-weight gain in growing animals. However, the change in physical condition of the diet alters also the digestibility of dietary constituents and probably the proportion of energy absorbed as fatty acids, and with some diets these effects may offset those due to the change in the relative proportions of VFAs. Thus, a growth response was obtained in steers given a diet of lucerne hay (I part), maize (I) and linseed-oil meal (0.04) (Shaw, Ensor, Tellechea \& Lee, 1960) but not in heifers given diets of hay and concentrates in the ratio of $3: 2$ or $2: 3$ (Broster \& Tuck, I96I). Moreover, Blaxter \& Graham (I956) observed no difference with sheep in the net energy value of dried grass when it was finely ground or in the long form.

It is, however, apparent that the proportion of acetate in the mixture of VFAs produced within the rumen is an important factor governing the efficiency with which the metabolizable energy (ME) of food is used for synthesis of body fat. The calorimetric observations of Kellner have shown (Breirem, 1944) that the efficiency of utilization for fat synthesis of ME consumed above the maintenance requirement decreases as the content of crude fibre in the diet increases and, since the proportion of acetic acid in rumen VFAs tends to be highest on high-fibre diets, clearly for a range of foodstuffs varying widely in composition a broad correlation between the efficiency of utilization of ME for fattening and the proportion of acetic acid in rumen VFAs will be found. With mature steers and sheep given diets containing various proportions of hay and concentrates and low in protein content, Blaxter (1962) has in fact demonstrated a close relationship. But, as he has indicated, more variation would be expected in comparisons of foods containing different proportions of protein, or of fat, since the VFAs would not then account for a constant proportion of the materials absorbed from the gut. It may be misleading, therefore, to explain observed differences in the efficiency of utilization for fattening of ME (Armstrong, 1960) or digestible energy (Milford, Minson \& Harris, 1961) of grasses solely in terms of an alteration in the relative production of the different VFAs.

An association between ruminal VFA production and milk fat content has been widely recognized since it was shown that the marked depression in fat content in cows given diets lacking in physical fibrousness is related to the concomitant increase in the ruminal production of propionic acid relative to that of acetic acid. Thus, the fall in milk fat content frequently noted in cows during the early grazing period is probably due to a relative increase in the ruminal production of propionic acid following the transfer from stall-feeding to grazing, a change which explains also the pronounced increase in solids-not-fat content commonly found at that time (Bath, Rook \& Rowland, 1962). The occasional increases in fat content noted may 
be related to the increases in the molar proportion of butyric acid found with certain swards.

A relationship between the ruminal production of acetic acid and the yield of milk has yet to be demonstrated under normal feeding conditions.

\section{REFERENCES}

Annison, E. F. (1954). Biochem. F. 57, 400.

Annison, E. F., Hill, K. J. \& Lewis, D. (1957). Biochem. F. 66, 592.

Annison, E. F., Leng, R. A., Lindsay, D. B. \& White, R. R. (1963). Biochem. F. 88, 248.

Annison, E. F. \& Lewis, D. (1959). Metabolism in the Rumen. London: Methuen \& Co. Ltd.

Annison, E. F., Lewis, D. \& Lindsay, D. B. (I959). F. agric. Sci. 53, 34.

Annison, E. F. \& Lindsay, D. B. (I96r). Biochem. F. 78, 777.

Armstrong, D, G. (1960). Proc. int. Grassl. Congr. vilı. Reading, p. 485.

Armstrong, D. G. \& Blaxter, K. L. (1957a). Brit. F. Nutr. II, 247.

Armstrong, D. G. \& Blaxter, K. L. (1957b). Brit. F. Nutr. I1, 4 I3.

Armstrong, D. G., Blaxter, K. L. \& Graham, N. McC. (1957). Brit. F. Nutr. Ix, 392.

Armstrong, D. G., Blaxter, K. L., Graham, N. McC. \& Wainman, F. W. (1958). Brit. f. Nutr. 12, 177.

Balch, D. A. (1958). Brit. F. Nutr. 12, 18.

Balch, D. A. \& Rowland, S. J. (I957). Brit. F. Nutr. II, 288.

Barcroft, J., McAnally, R. A. \& Phillipson, A. T. (1944). F. exp. Biol. 20, 120.

Bath, I. H., Balch, C. C. \& Rook, J. A. F. (1962). Proc. Nutr. Soc, 21, ix.

Bath, I. H. \& Rook, J. A. F. (r96r). Proc. Nutr. Soc. 20, xv.

Bath, I. H. \& Rook, J. A. F. (1963). F. agric. Sci. 6r, 341.

Bath, I. H., Rook, J. A. F. \& Rowland, S. J. (1962). Int. Dairy Congr. xvr. Copenhagen, I, 49.

Bensadoun, A., Paladines, O. L. \& Reid, J. T. (I962). F. Dairy Sci. 45, 1203.

Blaxter, K. L. (1962). The Energy Metabolism of Ruminants. I.ondon: Hutchinson.

Blaxter, K. L. \& Graham, N. McC. (1956). F. agric. Sci. 47, 207.

Breirem, K. (r944). K. LantbrAkad. Handl., Stockh., 83, 345.

Broster, W. H. \& Tuck, V. J. (I961) Rep. nat. Inst. Dairy., Reading, p. 42.

Brown, R. R., Davis, C. L., Staubus, J. R. \& Nelson, W. O. (1960). Y. Dairy Sci. 43, 1788.

Carroll, E. J. (1963). In Clinical Biochemistry of Domestic Animals, p. 59. [C. E. Cornelius and J. ]. Kaneko, editors.] New York: Academic Press Inc.

Carroll, E. J. \& Hungate, R. E. (1954). Appl. Microbiol. 2, 205.

Danielli, J. F., Hitchcock, M. W. S., Marshall, R. A. \& Phillipson, A. T. (1945). J. exp. Biol. $22,75$.

Davis, C. L., Brown, R. E., Staubus, J. R. \& Nelson, W. O. (г960). F. Dairy Sci. 43, 23 I.

el-Shazly, K. (1952a) Biochem. $\mathscr{F} . \mathbf{5 1}, 640$.

el-Shazly, K. (1952b). Biochem. F. 51, 647.

Essig, H. W., Norton, H. W. \& Johnson, B. C. (196r). Proc. Soc. exp. Biol., N.Y., 108, 194.

Gray, F. V., Jones, G. B. \& Pilgrim, A. F. (1960). Aust. F. agric. Res. I1, 383.

Gray, F. V. \& Pilgrim, A. F. (I95I). F. exp. Biol. 28, 83 .

Gray, F. V., Pilgrim, A. F. \& Weller, R. A. (1951). F. exp. Biol. 28, 74.

Halse, K. \& Velle, W. (1956). Acta physiol. scand. 37, 380.

Hogan, J. P. \& Phillipson, A. T. (I960). Brit. F. Nutr. 14, 147.

Hungate, R. E., Mah, R. A. \& Simesen, M. (196r). Appl. Microbiol. 9, 554.

Johns, A. T. (I955). N.Z.F. Sci. Tech. A, 37, 323 .

Lee, S. D. \& Williams, W. F. (1962). F. Dairy Sci. 45, 893 .

McCarthy, R. D., Shaw, J. C., McCarthy, J. L., Lakshmanan, S. \& Holter, J. B. (1958). Proc. Soc. exp. Biol., N.Y., 99, 556 .

Milford, R., Minson, D. J. \& Harris, C. E. (1961). Exp. Grassl. Res. Inst., Hurley, no. 13, p. 77.

Pfander, W. H. \& Phillipson, A. T. (1953). F. Physiol. r22, ro2.

Phillipson, A. T. \& McAnally, R. A. (I942). F. exp. Biol. 19, I 99.

Rook, J. A. F. \& Balch, C. C. (I961). Brit. F. Nutr. 15, 36r.

Rook, J. A. F., Balch, C. C., Campling, R. C. \& Fisher, L. J. (1963), Brit. F. Nutr. 17, 399.

Shaw, J. C. (196r). Int. Congr. Anim. Prod. vrrr. Hamburg, Vol. I, p. 29.

Shaw, J. C., Ensor, W. L., Tellechea, H. F. \& Lee, S. D. (1960). F. Nutr. 7r, 203.

Sheppard, A. J., Forbes, R. M. \& Johnson, B. C. (1959). Proc. Soc. exp. Biol., N.Y., ror, 7 I 5.

Stewart, W. E., Stewart, D. G. \& Schultz, L. H. (1958). F. Anim. Sci. 17, 723.

Storry, J. E. \& Rook, J. A. F. (1961). Biochim. biophys. Acta, 48, 6ro.

Sutherland, T. M. (1963). In Progress in Nutrition and Allied Sciences, p. 159. [D. P. Cuthbertson, editor.] Edinburgh: Oliver \& Boyd Ltd.

Sutherland, T. M., Ellis, W. C., Reid, R. S. \& Murray, M. G. (1962). Brit. F. Nutr. 16, 603. 
Terry, R. A. \& Tilley, J. M. A. (1961). Exp. Grassl. Res. Inst., Hurley, no. 13, p. 79.

Tilley, J. M. A., Deriaz, R. E. \& Terry, R. A. (1960). Proc. int. Grassl. Congr. vir. Reading, p. 533.

Williams, V. J. \& Christian, K. R. (1956). N.Z. F. Sci. Tech. A, 38, 403.

Wright, P. L., Pope, A. L. \& Phillips, P. H. (1963). F. Anim. Sci. 22, 586.

\section{Afternoon Session}

Chairman: J. Rowsell EsQ., JP, Stoke Charity, Near Winchester, Hants.

Factors affecting the voluntary intake of grass*

By R. C. Campling, National Institute for Research in Dairying, Shinfield, Reading

\section{Introduction}

Study of the factors controlling the intake of food by ruminants has been neglected for many years and it is only recently that interest among research workers has arisen. There are two good reasons why work is necessary on this subject. First, the most efficient animals are likely to be those that eat most per unit of body-weight (see Kleiber, 1936). Second, economic returns are often limited because the voluntary intake of the animal restricts the amount of cheap foods that can be utilized. Most often the cheap foods are grassland products, and it is with the voluntary intake of such foods by ruminants that this communication is primarily concerned; space permits only a brief discussion of the variation in voluntary intake between animals.

The term voluntary food intake is used to describe the amount of food eaten by an animal when food is offered $a d$ lib. The precise conditions under which voluntary food intake is measured must also be described, because many environmental factors can affect voluntary food intake, e.g. time of access to the food (Campbell \& Merilan, I961; Freer, Campling \& Balch, 1962). Unfortunately in animal husbandry the term palatability has become equated with voluntary food intake (Ivins, 1955; Garner, 1963) and differences between foods in the extent to which they are eaten have been attributed to differences between the foods in palatability. The voluntary intake of a food depends on the interaction between the animal and its food and, as Blaxter, Wainman \& Wilson (1961) have written, to describe a food as palatable and therefore attractive to the animal's palate involves appraisal of the animal's subjective evaluation of its food. I am in complete agreement with Blaxter and his colleagues that the term palatability should not be used in this context at all. This does not mean that the animal's senses of touch, smell and taste are unimportant in determining voluntary food intake, but rather that we know extremely little of these senses in ruminants and almost nothing of how they affect the intake of food. There is evidence that, when a single food only is given (Teitelbaum \& Epstein, r963), taste and smell

*Read at the joint meeting of The Nutrition Society and the British Grassland Society in London on 5 December 1963. Also published in the fournal of the British Grassland Society, Vol. 19, No. I, March 1964 . 